\title{
Enforcing Foreign Ownership Claims In The Antiquities Market
}

\author{
Jonathan S. Moore
}

Built on Mexico's Yucatan peninsula between 700 and 900 A.D., the ancient Mayan city of Oxhintok once sheltered an estimated 50,000 people. ${ }^{1}$ For unknown reasons, the Mayans abandoned the city some 1,000 years ago and the dense Central American forest soon buried all evidence of its urban form. When archaeologists first discovered the lost city, they eagerly embarked on its excavation, excited by the prospect of uncovering a rich trove of cultural and historic artifacts. Instead they found desolation. Lured by the promise of hidden treasure, looters in search of antiquities had dynamited buildings and sliced valuable stelae ${ }^{2}$ into pieces for clandestine shipment to the United States.

As Oxhintok illustrates, the lucrative trade in stolen antiquities ${ }^{3}$ fuels the destruction of ancient civilizations' archaeological records. ${ }^{4}$ Each time an antiquity is discovered and removed from a site without first being studied by anthropologists, the historical record that can be constructed through scientific evaluation of the piece in situ is destroyed. This Note examines legal methods that can most efficiently halt the continued devastation of archaeological sites.

Artifact-rich nations, the majority of which are developing countries, cannot protect their archaeological sites. ${ }^{\boldsymbol{E}}$ Many sites are located in remote regions and these nations lack the sophisticated customs services or police forces necessary to prevent looting. In an attempt to halt the theft and subsequent export of antiquities for sale in the United States, Europe and the Far East, many artifact-rich countries have passed legislation declaring that all antiquities of a specified age, whether below or above the

1. Yates, Treasures of the Maya, reprinted in Convention on Cultural Property Implementation Act: Hearings on H.R. 5643 and S. 2261 Before the Subcomm. on Int'l Trade of the Senate Comm. on Finance, 95th Cong., 2d Sess. 23 (1978) [hereinafter 1978 Senate Hearings].

2. These are stone slabs, "[o]ften 7 to 8 feet high and weighing several tons each,. . . Itheir inscriptions contain the] message of a vanished people, bearing names and dates and histories." Id. at 24.

3. As used in this Note, an antiquity is an object of cultural significance, generally more than 200 years old.

4. See K. Meyer, The Plundered Past (1973); Coggins, Archaeology and the Art Market, 175 SCIENCE 263 (1972).

5. Bator, An Essay on the International Trade in Art, 34 STAN. L. REv. 275, 289-94 (1982) (discussing extent of looting in South America, Europe and Asia). For a discussion of efforts to halt the trade see infra notes $21-26$ and accompanying text. 
ground, are owned by the nation. ${ }^{6}$ These "umbrella statutes" protect a source country's legal right to compel the return of nationalized artifacts from collectors and dealers in the United States in common law replevin actions. ${ }^{8}$ In addition, by clarifying that these antiquities are national property, the source countries subject purchasers of these artifacts in the United States to prosecution under criminal statutes that prohibit the importation of stolen property. ${ }^{9}$ Whether these umbrella statutes constitute valid declarations of ownership, however, remains a subject of considerable debate in the United States.

This Note proposes that United States courts recognize the ownership claims of artifact-rich nations. ${ }^{10}$ The enforcement of umbrella statutes is the most efficient means of limiting the continued destruction of archaeological data that the trade in antiquities promotes. Purchasers of antiquities, unlike the objects they acquire, are not hidden. For this reason, it is more effective to police the activity of antiquity purchasers than to protect archaeological sites. Strict enforcement of legal sanctions against collectors and dealers of antiquities will decrease the demand for new antiquities and reduce the economic incentive for looting. ${ }^{11}$

Section I of this Note documents the mechanics and magnitude of the trade in stolen antiquities and its destructive effects on cultural heritage and scientific knowledge. Section II analyzes the current proliferation of foreign umbrella statutes and the effectiveness of responsive American judicial and legislative remedies to curtail the illicit trade in antiquities. Section III offers economic and legal justifications for upholding umbrella statutes. Finally, Section IV outlines limits to the effectiveness of enforcing umbrella statutes as a means of halting the theft of antiquities.

6. This legislation typically establishes that all antiquities are government property. Even those not owned in a traditional sense, for example undiscovered antiquities in which no one has a possessory interest, are nationalized. If a developer discovers an antiquity during the excavation of a new building's foundation, the artifact is government property regardless of who owns the land and in spite of the fact that no one knew that the antiquity was located at this site prior to the excavation. Umbrella statutes are discussed in greater detail at infra notes 25-26 and accompanying text.

7. Only antiquities taken out of the country after the date the umbrella statute became effective could be considered stolen property.

8. "Replevin is a proceeding by which the owner. . [of] chattel taken or detained seeks to recover possession of that specific chattel. . . ." 66 AM. JuR. 2D Replevin $\S 2$ (1973). For a discussion of the common law theft rule see infra notes 28-30 and accompanying text.

9. The relevant statute is the National Stolen Property Act, 18 U.S.C. $\$ \S 2314-2315$ (1982). See discussion infra notes 31-32 and accompanying text.

10. Other countries' continued importation of stolen antiquities will limit the deterrent effect of the United States' recognition of umbrella statutes. Since the United States is one of the major importers of antiquities, the effect on the market should still be significant. See 1978 Senate Hearings, supra note 1, at 19 (statement of Mark Feldman, Deputy Legal Adviser, Department of State).

11. This proposal is not intended to serve as a legal basis for countries to seek the large scale return of antiquities that have already been stolen. See infra notes 103-104 and accompanying text. Rather, it offers a legal mechanism to limit the continued theft of artifacts and the irreplaceable loss of historical and cultural information that occurs when new artifacts are stolen. 


\section{The Trade in Stolen Antiquities}

The trade in stolen antiquities is flourishing. ${ }^{12}$ The bulk of this trade originates in developing countries and ends with sales in New York, London, Geneva and Tokyo. Collectors, dealers and museums, generating the demand for these treasures, display a tragic combination of artistic sophistication and an imperialistic attitude that developed countries have a right to hoard the world's antiquities. ${ }^{13}$ Instead of acknowledging that their demand for artistic treasures encourages the looting of archaeological sites, these collectors justify their actions by arguing that art-importing nations can better preserve a foreign country's heritage than can the country of origin. ${ }^{14}$

In fact, far from preserving objects of historical importance, the market demand for antiquities finances the looting of archaeological sites. ${ }^{15} \mathrm{~A}$ study in Belize revealed that "[l]ooting to supply the art markets of the art consuming nations, especially the United States, has been responsible for the greatest portion of the damage to sites"16 in that country. In Central

12. See B. Burnham, ARt TheFt: its SCOPE, ITS IMPACT, AND ITS CONTROL (1978); Ford, Looting the Past: An International Scandal, 14 Current AnTHropology 510 (1973); Carley, Stolen Treasure: Archaeological Objects Smuggled at Brisk Rate as Their Prices Soar, WaLL. Sr. J., June 2,1970 , at 1 , col. 1 . Trade in illicitly acquired art and artifacts is estimated to exceed $\$ 1$ billion annually. Lowenthal, Museum Repose Bill Vetoed in Albany, IFARrePORTs, July-Aug. 1986, at 3, 4 (quoting Marvin Stone, Deputy Director, United States Information Agency, in letter to New York Governor Mario Cuomo). Commentators often note that trade in stolen antiquities is second only to drug smuggling in terms of its importance as an international crime. See, e.g., A Special Agent Speaks Out, ART \& ANTIQuiries, Nov. 1986, at 59 (Kocaka interview).

13. Andre Emmerich, an antiquities dealer in New York City, typifies this perspective. He believes that "this country more than any other has a special claim to the arts of all mankind . . . ." $\mathrm{K}$. MEYER, supra note 4, at 28.

14. As one antiquities dealer testified before Congress: "The United States has been the greatest preserver of cultural properties from every country in the world, even in the days when these "cultural properties' were considered cultural garbage in their countries of origin." 1978 Senate Hearings, supra note 1, at 49 (testimony of art dealer Peter Marks). Furthermore, collectors contend that antiquities bought and sold on the market are often commonplace items that deserve no special protection. As Emmerich testified, these artifacts "are generally remarkably repetitive . . . . Most early tombs contain the cultural equivalents of Coca Cola bottles, Seven-Up cans and mass-produced rosary beads .... What would be invaluable and instructive additions to the collections of many American museums are simply left unseen and endangered on local premises supposedly dedicated to their preservation." Id. at 51 .

15. See generally Bator, supra note 5, at 291 ("[I]ncrease of interest among art collectors . . . . has fueled an intense world-wide search for such [primitive and ethnographic] art.") (footnote omitted); K. MEYER, supra note 4, at 139 (until recently most Indian idols left unharmed, but as value of Indian art escalated, theft of idols became commonplace); Shirey, Norton Simon Bought Smuggled Idol, N.Y. Times, May 12,1973, at 1, col. 2 (Simon claimed to have spent $\$ 15-16$ million on Asian art, most of which was smuggled). The high prices that these objects fetch reflect the market's strength. See Dunn, Personal Business, Bus. WK., Jan. 20, 1986, at 93 (pre-Columbian work recently sold for $\$ 175,000$ ); N.Y. Times, Feb. 10, 1988, at C18, col. 6 (Mayan vase sold in 1984 for $\$ 515,000)$; Wellborn, When Greedy Collectors Plunder the Past, U.S. NEws \& WorLd REPORT, March 4, 1985, at 79 (Mayan vase may cost $\$ 15,000$; Mayan monolith may cost $\$ 125,000$ ).

16. Gutchen, The Destruction of Archaeological Resources in Belize, Central America, $10 \mathrm{~J}$. Field ARChaeology 217, 227 (1983). Gutchen's survey revealed that $74.3 \%$ of all major ceremonial centers in Belize had been looted. Id. at 222. For a more general discussion of how looting is financed, see K. MEYER, supra note 4, at 156-63. 
America alone, millions of dollars worth of cultural patrimony is stolen every year. ${ }^{17}$

A country can retrieve the physical forms of its cultural heritage by recovering artifacts that have been removed. ${ }^{18}$ The damage inflicted by looters on the body of scientific knowledge that undiscovered artifacts represent, however, is irreparable. ${ }^{19}$ Anthropological archaeologists depend on undisturbed sites for noting and calculating the precise relationship among artifacts. ${ }^{20} \mathrm{By}$ recording the amount of a certain fragment type within a room, or the spatial distribution of remains, much can be learned about the habits and culture of ancient civilizations. When looters unearth antiquities, anthropological data, in many cases the only historical record available for source countries, is lost forever.

Artifact-rich nations are in a complex predicament. In the face of the enormous pressure that the market demand for their cultural past creates, these countries have had little success preventing the looting of archaeological sites. Physical protection of sites is simply not feasible. ${ }^{21}$ Police,

17. It is estimated that more than $\$ 30$ million of antiquities are stolen from Costa Rica every year. 1978 Senate Hearings, supra note 1, at 20 (statement of Rep. Abner Mikva). The value of artifacts removed from the Yucatan (Mexico) and Guatemala ranges between $\$ 20-\$ 50$ million a year. 1978 Senate Hearings, supra note 1, at 24 (Yates reprint). For a discussion of the extent of looting in coastal Ecuador, see Damp, Salvaging Sites and Specimens: To Fake or Not to Fake, 11 J. FIELD ARCHAEOLOGY 427 (1984).

18. For example, in 1973, Peace Corps volunteers located the Afo-A-Kom, a statue said to embody the soul of the Kom, a Cameroonian tribe, in a New York art gallery. The piece was of such importance to the Kom that its discovery led to an international incident and the statue's eventual return. DuBoff \& Allan, The Afo-A-Kom: A Plea to Save A Cultural Heritage, in ART LAw: DoMESTIC and InTERnational 425 (1975); see also Merryman, Thinking About the Elgin Marbles, 83 Mich. L. REv. 1881 (1985) (discussing efforts of Greek government to have British Museum return Elgin Marbles, sculptures taken from Parthenon by Earl of Elgin in early 1800's).

19. Looters systematically destroy entire archaeological sites. The professional looter comes equipped with portable generators, prefabricated huts, power tools and metal detectors. The financial resources, sophistication and brutality of looters are legendary. Eric von Euh, a Yale archaeologist, recounted how looters financed by a New York art dealer built landing strips in the jungles of Central America, and flew in old DC-3 cargo planes to remove artifacts. 1978 Senate Hearings, supra note 1 , at 25 (Yates reprint).

20.

[O]ur archaeological resources are not renewable. Once a site has been worked over by looters in order to remove a few salable objects, the fragile fabric of its history is largely destroyed. Changes in soil color, the traces of ancient floors and fires, the imprint of vanished textiles and foodstuffs, the relation between one object and another, and the position of a skeleton-all of these sources of fugitive information are ignored and obliterated by archaeological looters. . . . The collector buys a beautiful object about which he knows virtually nothing, and no one ever mentions to him the devastation that was created in order to deliver it.

Coggins, supra note 4, at 263.

21. Artifact-rich nations have thousands of existing archaeological sites that must be protected from looting. The local police forces are not able to ensure that these sites are not harmed by looters. 1978 Senate Hearings, supra note 1, at 22 (testimony of Rep. Abner Mikva); K. MEYer, supra note 4, at 154 (describing limited finances to protect archaeological resources); Relating to Stolen Archaeological Property: Hearings on $\$ 605$ Before the Subcomm. on Crim. Law of the Senate Comm. on the Judiciary, 99th Cong., 1st Sess. 147 (1985) (testimony of Dr. Albert A. Denkin, Jr., Society for American Archaeology) (hereinafter 1985 Senate Hearings]; UNITED NATIONS Social. DefENCE Research Institute, Pub. No. 13, The Protection of the Artistic and Archaeological Heritage 221 (1976) (discussing protection of Indian temples).

Even the United States cannot protect its own archaeological treasures. A rise in the market price of 
customs agencies and other enforcement units are understaffed and poorly paid. ${ }^{22}$ Furthermore, some of the most damaging looting occurs in previously unknown sites, such as Oxhintok, which are not discovered until it is too late. These sites cannot be protected.

Unable to police sites, many source countries enacted export regulations that prohibit the removal of all antiquities. ${ }^{23}$ Developing countries, however, cannot police their borders. Many importing countries, such as the United States, do not enforce foreign nations' export laws. ${ }^{24}$ Thus, in spite of the efforts of developing countries, the trade in stolen antiquities continues to thrive.

Artifact-rich nations realize that deterrents must be placed on purchasers in order to slow the trade in antiquities. To accomplish this, many source nations have passed umbrella statutes which declare that all antiquities of a certain age or older (whether discovered or still buried, whether held in public or private hands) are national property. ${ }^{25}$ In addition, they have required that anyone who already possesses artifacts register them with the government. ${ }^{28}$ This legislation transforms the character of antiq-

Native American artifacts (a ceremonial basket used by Hopi Indians can be worth $\$ 120,000$ ) has resulted in increased looting in the Southwest. See Goodwin, Raiders of the Sacred Sites, N.Y. Times, Dec. 7, 1986, $\$ 6$ (Magazine), at 65 . As in Central America, in spite of protective legislation, the trade continues. Currently it is estimated that $80-90 \%$ of all sites in the Southwest have been looted. Id. at 66 .

22. A smuggler wishing to export an artifact can often obtain an export certificate illegally or bribe a customs official at the border. See L. DuBoff, The Deskbook of ART LAw 71 (1977) (some people in underdeveloped countries willing to sacrifice cultural heritage for improved standard of living); K. MEYER, supra note 4, at 140 (guards at Indian temples paid less than 50 cents per day); see United States v. Hollinshead, 495 F.2d 1154, 1155 (9th Gir. 1974) (officers received bribes in export of artifacts); L. DuBoff, supra, at 109-14 (discussion of theft of an important Indian idol, Swapuram Nataraja, for which false export permits were received). See also Ferretti, Owner Returning Statue to Kom, N.Y. Times, Oct. 31, 1973, at 35, col. 2 (two Cameroonians reportedly accepted $\$ 20$ in bribes to allow export of Afo-A-Kom).

23. See 1\&2 United Nations Educational, Scientific and Cultural Organization, The Protection of Movable Cultural. Property: Compendium of Legislative Texts (1984); S. Williams, The International and National. Protection of Movable Culturai. Property: A Comparative Study 108-17 (1978); 1 L. Prott \& G. O'Keefe, Law and the Cultural. Heritage (1984); B. Burnham, Handbook of National Legislation (1975).

24. Under customary international law, a United States importer of objects illegally exported from a foreign nation will not be prosecuted. For a discussion of customary international law on this subject see S. Williams, supra note 23, at 106-08. No United States court or legislative authority has ever recognized a cause of action solely for possession of illegally exported objects. See Bator, supra note 5 , at $287 \&$ n.30. But see exception under International Convention discussed infra note 36.

25. These decrees apply to artifacts currently in collections as well as works that have not been discovered. The prospective dimension of these statutes is problematic. Countries can easily demonstrate ownership of objects that, prior to nationalization, were located in the homes of citizens. The registration of these artifacts would define the country's claim. It is more difficult to show that artifacts unearthed after nationalization occurred are owned by the country.

26. Many countries have passed umbrella ownership statutes for at least some types of antiquities. In Mexico, the first declarations of national ownership of antiquities were passed in 1897, Article 1 of the Law on Archaeological Monuments, May 11, 1897, Diario oficial de 11 de Mayo de 1897, see XIV Anuario de Legislacion y Jurisprudencia 323 [1897] (declaring archaeological monuments property of the nation). More expansive legislation was passed in 1930 (Law on the Protection and Conservation of Monuments and Natural Beauty, 58 D.O. 7 (1930)), 1934 (Law for the Protection and Preservation of Archaeological and Historic Monuments, Typical Towns and Places of Scenic Beauty, 82 D.O. 152 (1934)), and 1970 (Federal Law Concerning Cultural Patrimony of the Nation, 303 
uities, previously controlled only by export regulations not enforced by the United States, into stolen property that is subject to United States common law and statutory regulations.

\section{Restrictions on the Trade in Stolen Property: The Common Law Rule and the National Stolen Property Act}

The common law theft rule and the National Stolen Property Act $(\mathrm{NSPA})^{27}$ restrict the trade in stolen property. Foreign nations can bring common law replevin actions in United States courts against any holder of stolen property, whether or not she is a good faith purchaser. The common law rule, as codified in the Uniform Commercial Code (U.C.C.), ${ }^{28}$ is that a purchaser cannot acquire good title from a thief. This rule places all liability on purchasers. A buyer might pay for an item not knowing it is stolen and then if the original owner locates the object, the purchaser must return it to the original owner. If the purchaser of the stolen goods cannot locate the party from whom she bought the object, she will not be compensated for her loss. ${ }^{29}$ In short, even good faith purchasers, who have no idea that an item was stolen, may have to forfeit the property. ${ }^{30}$

The NSPA prohibits the transport, receipt, concealment, and sale of

D.O. 8 (1970)). On May 6, 1972 the Federal Law on Archaeological, Artistic and Historic Monuments and Zones, 312 D.O. 16 (1972), was enacted. Relevant articles include Article 27, which provides that "[a]rchaeological monuments, movables and immovables, are the inalienable and imprescriptible property of the Nation," and Article 28 which provides that "[m]ovable and immovable objects, product of the cultures prior to the establishment of the Spanish culture in the National Territory,... . are archaeological monuments." Furthermore, Article 22 required individuals to register monuments "of their ownership."

In Guatemala, all "[a]rchaeological monuments and relics" are "assets of the state." Guat. ConST. art. 121(f).

Other Latin American countries which have passed umbrella statutes include Belize, Costa Rica, Nicaragua, Panama, El Salvador, Argentina, Brazil, Bolivia, Chile, and Venezuela. See Note, Harmonious Meeting: The McClain Decision and the Cultural Property Implementation Act, 19 CornelL INT'L L.J. 311,329 n.135 (citing specific laws recognized by the United States). The State Department also has mentioned the following nations as those which have passed national ownership statutes: Haiti, Egypt, Greece, Iraq, Jordan, Kuwait, Lebanon, Turkey, Algeria, Liberia, Mauritania, Nigeria, Tanzania and Tunisia. 1985 Senate Hearings, supra note 21, at 49 (testimony of Ely Maurer, Assistant Legal Adviser, Department of State).

27. 18 U.S.C. $\$ \S 2314-2315$ (1982).

28. U.C.C. $\$ \S 2-401,2-402,2-403$ (1977); J. WhITE \& R. SUMmERS, UNiform CoMmercial CODE 550-75, 798-809 (2d ed. 1980).

29. For an argument defending the common law's efficiency see Weinberg, Sales Law Economics, and the Negotiability of Goods, 9 J. LEg. STud. 569 (1980). But see Murray, Sale in Market Overt, 9 INT'L \& CoMP. L. Q. 24 (1960) (arguing that favoring owner's claim over innocent purchaser is injurious to commerce).

30. See, e.g., Menzel v. List, 22 A.D.2d 647, 253 N.Y.S.2d 43 (1964) (denying defendant's motion to dismiss), enforced, 49 Misc. 2d 300, 267 N.Y.S.2d 804 (1966) (denying motion to set aside judgment against defendant), affd as modified, 28 A.D.2d 516, 279 N.Y.S.2d 608 (1967) (per curiam) (modifying damages award), rev'd, 24 N.Y.2d 91, 246 N.E.2d 742, 298 N.Y.S.2d 979 (1969) (good faith purchaser of painting by Marc Chagall, taken from original owner by Nazi troops in 1941, forced to forfeit work to original owner); Johnny Dell, Inc. v. New York State Police, 84 Misc. 2d 360,375 N.Y.S.2d 545 (1975) (good faith purchaser of automobile from individual who purchased car from thief did not obtain title and must return vehicle to original owner). 
goods worth $\$ 5,000$ or more, "knowing the same to be stolen." 31 Thus, an individual who transports, sells or purchases an antiquity must know that it is stolen in order to be prosecuted for a violation of the NSPA. ${ }^{32}$

The NSPA provides an effective means of prosecuting dealers in stolen antiquities and of obtaining the return of artifacts to the source country. ${ }^{33}$ Common law replevin actions provide an even more straightforward means of recovering stolen antiquities. ${ }^{34}$ Foreign governments and citizens have routinely succeeded in obtaining the return of objects that fall within the traditional definition of "stolen" in common law replevin actions. ${ }^{35}$ The critical limiting factor of both the common law and the NSPA is that they apply to antiquities illegally removed from a foreign country and imported into the United States only if the property falls within the United States' legal definition of "stolen." Thus, the effectiveness of these laws in slowing the theft of antiquities hinges on that definition. ${ }^{36}$

31. See supra note 27.

32. The scienter requirement is not an insurmountable barrier. If the accused is aware that the goods were stolen from somewhere, conviction is possible; she need not be aware of exactly which foreign law proclaimed the artifacts national property. See United States v. Hollinshead, 495 F.2d 1154, 1156 (9th Gir. 1974).

33. The NSPA is an attractive remedy for foreign nations. Violators of this statute are prosecuted by the United States. Following a criminal conviction under the NSPA, the disposition of the artifacts is determined in a forfeiture proceeding. If the United States wins custody of the artifact, the return of the object to the foreign government is usually negotiated. See United States v. One Eighteenth Century Colombian Monstrance, 797 F.2d 1370 (5th Cir. 1986); see also L. DuBofF, supra note 22, at 96 (discussion of stolen artifacts returned to Guatemala). If the United States brings an NSPA action the cost of prosecution is paid by the United States government. The NSPA's criminal sanctions are a greater deterrent than replevin, which simply forces the holder of the stolen work to return it to the country of origin.

34. A replevin suit may be brought without the United States government's participation and requires no negotiation for return of the object. Plaintiffs need not demonstrate scienter and the country of origin may be more capable than the United States of determining which objects have been stolen from within its borders.

35. See, e.g., Federal Republic of Germany v. Elicofon, 536 F. Supp. 813 (E.D.N.Y. 1978); Kunstsammlungen Zu Weimar v. Elicofon, 536 F. Supp. 829 (E.D.N.Y. 1981), affd, 678 F.2d 1150 (2d Cir. 1982). The Second Circuit affirmed a district court's determination that two priceless Durer paintings, stolen from a castle in Germany and purchased by a Brooklyn collector from a United States serviceman, belonged to the Kunstsammlungen Zu Weimar, a museum owned and operated by the East German government. "In applying the New York rule that a purchaser cannot acquire good title from a thief, New York courts do not concern themselves with the question of where the theft took place, but simply whether one took place." Elicofon, 536 F. Supp. at 846. Accord Mucha v. King, 792 F.2d 602 (7th Cir. 1986) (Czechoslovak citizen brought successful action for return of painting illegally converted by Chicago gallery and subsequently purchased by defendant for $\$ 35,000$ ); DeWeerth v. Baldinger, 658 F. Supp. 688 (S.D.N.Y. 1987) (German citizen from whom Monet painting had been stolen obtained this work from defendant, who purchased painting in good faith from Wildenstein gallery), rev'd, Nos. 87-7392. 87-7402 (2d Cir. Dec. 30, 1987) (LEXIS, Genfed library, Usapp file) (DeWeerth failed to exercise due diligence in seeking painting's return).

Givil suits have also been initiated for the return of antiquities stolen from museums and monuments. Guatemala instituted a civil action in California in 1970 for the return of a Mayan stela stolen from a site that had been carefully catalogued in that country. See L. DuBoff, supra note 22, at 91 . The United States instituted criminal action against the thief under the NSPA. Id. See also 2 F. FEldman, S. Weil \& S. Bierderman, ART LAW $\S 11.2 .5$ (1986) (discussing suit brought by Rumanian Government against private gallery and museum seeking return of El Greco painting) [hereinafter FELDMAN \& WEIL]; L. DuBofF, supra note 22, at 110-14 (discussing civil suit brought by Indian Government for return of stolen idol).

36. An alternative means of limiting the trade in stolen antiquities is the use of treaties and 


\section{A. Can Newly Discovered Antiquities Be Considered Stolen?}

Historically, property was defined as stolen when the original holder was deprived of rights of ownership. ${ }^{37}$ In the case of an ancient urn, the owner may well be buried in it. There are no traditional ownership rights in this situation.

A nation's claim to own its cultural patrimony is not equivalent to the ownership interest in more traditional forms of property. When a country claims ownership of an antiquity for sale in a New York gallery, the country cannot produce the type of evidence of ownership that is available to the owner of a stolen car. For the latter, the registration certificate the purchaser holds, the time spent driving to work and the receipt given the owner by the dealership for the vehicle, all define the buyer's ownership. A country that declares itself owner of undocumented antiquities does not possess similar tangible proof. There are no registration permits and prior to the discovery of the antiquity its existence may not have been known. In fact, the antiquities are often discovered by the thieves.

international conventions. The most significant legislation is the Convention on Cultural Property Implementation Act (CPIA), 19 U.S.C. $\$$ 2601-2613 (1982). This implemented the UNESCO Convention on the Means of Prohibiting and Preventing the Illicit Import, Export, and Transfer of Ownership of Cultural Property, Nov. 14, 1970, 823 U.N.T.S. 231 (1972). This statute provides a mechanism for limited enforcement by the Customs Service of a foreign nation's export laws. A foreign country that wants to avail itself of the CPIA's protection must request United States assistance and demonstrate: (1) that archaeological and ethnological material is in danger of pillage; (2) that the country has made due efforts to prevent such theft; and (3) that any United States import restrictions will be applied in concert with other nations, through bilateral or multilateral agreements. The CPIA is discussed in detail in Note, supra note 26.

Given the reluctance of other artifact-importing nations to limit this trade, implementation of import restrictions is unlikely. To date, only Canada and El Salvador have made requests in accordance with this legislation. The U.S. has yet to act on either of these petitions. See IFARrEPORTS, June 1987 , at 6.

The strict enforcement of customs regulations also provides a means to limit the trade in stolen antiquities. In accordance with prohibitions against smuggling, an importer of merchandise contrary to law is subject to criminal sanctions and forfeiture of such merchandise to the United States, 18 U.S.C. § 545 (1982). Since the United States prohibits transport of stolen goods worth more than $\$ 5,000,18$ U.S.C. $\$ 2314$ (1982), a customs inspector who suspects that valuable artifacts have been stolen can hold such goods until title has been determined. The Customs Service frequently found that in an effort to mask the theft of valuable antiquities, imported items are incorrectly described and undervalued in violation of customs regulations. Goods that are falsely categorized or not declared are subject to forfeiture and the importer is liable for fines that equal the value of the imported object, 19 U.S.C. § 1497 (1982). Items seized by customs are usually returned to the country of origin. See, e.g., U.S. Customs Service, Supp. No. 3280 01 , Seizure and Detention of PRe-Golumbian ARtifacts, Policies and Procedures Manual. (Oct. 5, 1982); Mitgang, Recovered Peruvian Art Raises Cultural Issues, N.Y. Times, Aug. 5, 1982, at C15, col. 1 (discussing settlement between art dealer David Bernstein and United States Customs Office result of which was return of 700 artifacts to Peru). However, because artifacts are hard to detect and the veracity of their descriptions are difficult to assess, the Customs Service cannot prevent the entry of many illicit imports into the United States market. See, e.g., A Special Agent Speaks Out, supra note 12, at 59 (discussing investigatory work of customs agent specializing in art theft).

37. "Stealing . . . is commonly used to denote any dishonest transaction whereby one person obtains that which rightfully belongs to another, and deprives the owner of the rights and benefits of ownership . . . " Crabb v. Zerbst, 99 F.2d 562, 565 (5th Cir. 1938). This definition was cited with approval in United States v. Handler, 142 F.2d 351, 353 (2d Cir.), cert. denied, 323 U.S. 741 (1944). 
Under an expansive definition of ownership and theft, ${ }^{38}$ if the buried urn was discovered and removed by a huaguero, ${ }^{39}$ smuggled to the United States, sold to a gallery, and purchased by a private collector or museum, the artifact would be considered stolen property even though the traditional owner had long since disappeared. ${ }^{40}$

Such broad definitions of "ownership" and "stolen" need to be accepted by the courts for the common law and the NSPA to assist countries victimized by looters. Umbrella statutes provide precisely these broad definitions of ownership and theft. The continued theft of new artifacts will be slowed if United States courts recognize that umbrella statutes are legitimate declarations of ownership and that any antiquity illegally removed from these countries is stolen. ${ }^{41}$ To date, courts have applied an expansive definition of ownership to antiquities. This interpretation is threatened, however, by legislative efforts to impose a narrow definition of ownership on imported antiquities.

\section{B. Judicial Interpretation}

A United States court first upheld the validity of an umbrella ownership statute in United States $v$. Hollinshead. ${ }^{\mathbf{4 2}}$ Hollinshead was convicted of violating the NSPA for stealing Machaquila Stela II from Guatemala. Under a Guatemalan ownership statute, the country was the owner of the Stela. In upholding his conviction, the Ninth Circuit reiterated that all the NSPA required was that Hollinshead knew that the Stela was stolen. It was not necessary to show that he was aware of applicable Guatemalan law. ${ }^{43}$ The presence of Machaquila Stela II in the jungles of Guatemala

38. "Stolen" has no accepted common law definition. See United States v. Turley, 352 U.S. 407, 411 (1957) (discussing meaning of word "stolen" in 18 U.S.C. $§ 2312$ (1982)); Zerbst, 99 F.2d at 565. Furthermore, stolen is not a "term of art." Turley, 352 U.S. at 412 (quoting Boone v. United States, 235 F.2d 939, 940 (4th Cir. 1956)). In cases decided after Turley, courts have interpreted "stolen" broadly. See United States v. Vicars, 465 F.2d 720 (6th Cir. 1972) (defendant who fraudulently traded non-airworthy airplane for airworthy airplane found to have "stolen" the latter); United States v. Bottone, 365 F.2d 389 (2d Cir.), cert. denied, 385 U.S. 974 (1966) (photocopies that revealed technical data from documents were "stolen").

39. Huaguero is a Peruvian word used to describe those who plunder tombs and loot archaeological sites. K. MEYER, supra note 4, at 132 .

40. A country can claim to own as yet undiscovered artifacts. The United States claims ownership of Indian artifacts that have not been unearthed. See infra notes 77-80 and accompanying text. Similarly, nations throughout the world claim ownership of undiscovered natural resources. See infra note 84.

41. Since a source country's ownership in antiquities is not equivalent to a purchaser's interest in more traditional forms of property, limits should be imposed on the enforcement of foreign nations' umbrella statutes. At a minimum, United States courts should only recognize the blanket ownership statutes of those countries which strictly enforce these laws within their own borders. As discussed in Section III, infra p.477, there are legal and economic rationales for why, in instances when umbrella ownership statutes are consistently applied by a foreign country, they should be recognized by United States courts.

42. 495 F.2d 1154 (9th Cir. 1974). Clive Hollinshead, a dealer in pre-Columbian artifacts, was prosecuted for conspiring to transport and transporting stolen property in violation of the NSPA.

43. Following Hollinshead's conviction under the NSPA the disposition of the artifact was determined in a forfeiture proceeding. United States v. One Pre-Columbian Artifact, No. CV73-2349-FW 
had been documented prior to the theft. ${ }^{44}$ This documentation, in conjunction with Guatemala's umbrella ownership statute, removed all doubt that the work was owned by Guatemala. Since artifacts are rarely catalogued with such precision, however, the court's holding had limited relevance to the trade in antiquities.

In United States $v$. McClain, ${ }^{45}$ the Fifth Circuit considered more fully the question of whether an artifact can be considered stolen if its ownership is based solely on a national government's umbrella ownership statute. ${ }^{46} \mathrm{McGlain}$ and her co-defendants were arrested for transporting and receiving stolen property in violation of the NSPA. They had attempted to sell pre-Columbian artifacts to the Mexican Cultural Institute in San Antonio, Texas. ${ }^{47}$ The basis of Mexico's claim of ownership was its umbrella ownership statutes. ${ }^{48}$

The defendants did not deny that the artifacts had been illegally exported from Mexico. Thus a key question facing the court was whether the illegal export of these objects from a country with a blanket ownership statute was sufficient evidence of theft. ${ }^{49}$ In Hollinshead the court's finding was confirmed by evidence that this exact Stela had been catalogued while still in the Guatemalan forest. The disputed artifacts in McClain had not been previously documented. ${ }^{50}$ The court stated that "a declaration of national ownership is necessary before illegal exportation of an article can be considered theft, and the exported article considered 'stolen,' within the meaning of the National Stolen Property Act." ${ }^{\text {.51 }}$ Further, it held that Mexico's umbrella statutes, ${ }^{52}$ combined with laws that restricted the export of artifacts, were sufficient authority for bringing and winning an action under the NSPA. ${ }^{53}$

McClain illustrates how ownership statutes should work: A foreign country with an umbrella statute notifies the United States government that an antiquity sold in the United States has been illegally exported, is

(C.D. Cal. 1975). The Court granted summary judgment to the United States and the artifact was subsequently returned to Guatemala in accordance with an exchange agreement between the Guatemalan Government and the Los Angeles County Museum. L. DuBoff, supra note 22, at 96, 981.

44. Against all odds, a prospective purchaser of the Stela showed pictures of this work to an archaeologist, Ian Graham, who had studied this exact Stela in Guatemala. Graham immediately realized that the artifact being offered for sale had been stolen. L. DuBorf, supra note 22, at 91 .

45. United States v. McClain, 545 F.2d 988 (5th Cir.) [hereinafter McClain I], reh'g denied per curiam, 551 F.2d 52 (1977); United States v. McClain, 593 F.2d 658 (5th Cir.) [hereinafter McClain II], cert. denied, 444 U.S. 918 (1979).

46. McClain I, 545 F.2d at 1000-03.

47. The NSPA has been consistently applied to goods stolen in foreign countries and then imported into the United States. See McClain I, 545 F.2d at 994.

48. See supra note 26 .

49. McClain I, 545 F.2d at 994-97.

50. Id. at 992 .

51. Id. at 1000-01 (footnote omitted).

52. The court concluded that in 1972 the Mexican government extended national ownership to all pre-Columbian art. In so holding, it reversed the lower court's finding that Mexico had owned all pre-Columbian art since 1897 . Id. at 1000 .

53. Id. at 1001 . 
not properly registered, and is therefore stolen property. The country also asserts that such property would be considered stolen if located inside as well as outside of the nation's border. The United States government, recognizing the ownership statute, prosecutes the art dealer for theft under the NSPA. Finally, the United States courts recognize the ownership laws and punish those individuals who have knowingly received or transported the stolen property. Once these umbrella statutes are recognized, foreign countries can seek the return of antiquities from buyers in common law replevin actions regardless of whether these buyers knew the objects to be stolen.

\section{Legislative Response}

Legal commentators and legislators have condemned the McClain decision. $^{54}$ They argue that recognition by U.S. courts of umbrella ownership statutes places too much risk on purchasers. ${ }^{55}$ Further, McClain has engendered a broad-based effort to codify a narrow interpretation of "ownership" and "stolen" that protects purchasers. Legislation to reverse the holding of the court in McClain was introduced in the 97th, 98th and 99th Congresses.

In 1985, two bills were introduced to limit the impact of McClain. Senator Moynihan proposed a bill to amend the NSPA so that it would not apply to artifacts whose ownership is based solely on a nation's declaration that such objects are its property. ${ }^{56}$ Senator Mathias introduced the

54. Several bills have been introduced to reverse the McClain decision. See S. 1523, 99th Cong., 1st Sess., 131 Cong. Rec. 10,288 (1985); S. 605, 99th Cong., 1st Sess., 131 Cong. Rec. 2611 (1985); S. 1559, 98th Cong., 1st Sess., 129 Cong. Rec. 9343 (1983); S. 2963, 97th Cong., 2d Sess., 128 Cong. REc. 12,418 (1982); Cultural Property Repose Act: Hearings on S.1523 Before the Subcomm. on Patents, Copyrights and Trademarks of the Senate Comm. on the Judiciary, 99th Cong., 2d Sess. (1986) [hereinafter 1986 Senate Hearings]; 1985 Senate Hearings, supra note 21; 1978 Senate Hearings, supra note 1.

New York has also introduced legislation to limit the impact of McClain. S. 3273, 208th Leg, 1985 (bill recalled after Attorney General opposed); A. 11462, 209th Leg., 1986 (vetoed by Governor Cuomo on July 28, 1986); Bator, supra note 5, at 350-54; Fitzpatrick, A Wayward Course: The Lawless Customs Policy Toward Cultural Properties, 15 N.Y.U. J. INT'L. L. \& PoL. 857 (1983); McAlee, The McClain Case, Customs and Congress, 15 N.Y.U. J. INT'L. L. \& PoL. 813 (1983); Note, United States v. Hollinshead: A New Leap In Extraterritorial Application of Criminal Lau's, Hastings InT'L \& CoMp. L. Rev. 149 (inaugural issue Spring 1977); Note, Art Theft: National Stolen Property Act Applied to Nationalized Mexican Pre-Columbian Artifacts-United States v. McClain, 10 N.Y.U. J. INT'L L. \& Pol. 569 (1978).

55. This analysis overlooks the theory behind the common law rule: ensuring that a purchaser can never obtain good title from a thief is an effective means of deterring theft. For a discussion of the theft rule see A. Schwartz \& R. ScotT, Commercial Transactions 476-79 (1982). It is without force, then, for critics of $\mathrm{McClain}$ to urge the reversal of this decision on the grounds that it places excessive liability on purchasers. Liability for purchasers of stolen property is not new. The only real question is whether an antiquity that a source country claims to own by virtue of an umbrella statute, that is unearthed and exported into this country, should be considered stolen property by United States courts.

56. Legislation has sought to exclude from the NSPA:

archaeological or ethnological materials taken from a foreign country where - (1) the claim of ownership is based only upon - (A) a declaration by the foreign country of national ownership of the material; or (B) other acts by the foreign country which are intended to establish owner- 
Cultural Property Repose Act. ${ }^{57}$ This bill proposed a five-year federal statute of limitations on claims brought for the recovery of stolen archaeological or ethnological material held in the United States. Additionally, the legislation proposed a two-year statute of limitations on stolen antiquities held by recognized museums, religious or secular monuments, or similar institutions, provided that the objects had been exhibited or their presence made known through publication, cataloguing or otherwise. ${ }^{58}$

Efforts to limit the McClain decision have come from the states as well. Individual states have different statutes of limitation for stolen art. ${ }^{58}$ In New York, the statute of limitations does not begin to run until after the purchaser refuses the owner's demand for the object's return. ${ }^{60}$ Legislation was introduced in New York in 1985 and 1986 that would have created an exception to the demand and refusal rule for museums that purchase antiquities. ${ }^{61}$ The bill provided for a three-year statute of limitations that would start to run as soon as the object was stolen. In addition, the bill did not require a "demand" on the part of the owner if the museum published notice of the acquisition in its bulletin, displayed the object for at least twelve months, and noted the object in the museum's catalogue for three years. It would be difficult for an artifact-rich nation to locate stolen objects within the statute of limitations. In many cases, years pass before

\footnotetext{
ship of the material and which amount only to a functional equivalent of a declaration of national ownership; (2) the alleged act of stealing, converting, or taking is based only upon an illegal export of the material from the foreign country. . . .

S. 605, 99th Cong., 1st Sess., 128 ConG. REC. 2611-12 (1985).
}

57. S. 1523, 99th Cong., 1st Sess., 131 Cong. Rec. 10,288 (1985). Apparently, a private collector retained the Houston law firm, Vinson \& Elkins, to draft the bill and seek support for it. Those testifying in favor of this legislation included the directors of the St. Louis Art Museum and the Houston Museum of Fine Arts. Herscher, Senate Holds Hearings on Cultural Property Repose Act, $13 \mathrm{~J}$. Field Archaeology 332 (1986).

58. This legislation "would override the law of New York and other jurisdictions with respect to suits brought by foreign governments . . . to recover stolen cultural items." 1986 Senate Hearings, supra note 54, at 22 (statement of Ely Maurer, Assistant Legal Adviser, Department of State). Senator Bentsen argued that the bill was a necessary response to attempts by foreign governments to circumvent the Texas statute of limitations. As an example he cited the recently dismissed case brought against the Kimbell Art Museum by the Rumanian government for the return of two El Greco paintings. Rumania claimed that the works had been stolen from the country in the 1940's. The Kimbell Museum purchased them in 1977. N.Y. Times, Jan. 10, 1986, at C15, col. 3.

Foreign countries have recently increased their efforts to seek the return of cultural property. See Collectors or looters?, EcoNomist, Oct. 17, 1987 (discussing recent efforts by Turkey and Ecuador to seek return of cultural property); Crossette, Thais Accuse U.S. in Loss of Temple Art, N.Y. Times, Feb. 10, 1988 (recent efforts of Thai Government to seek return of stolen antiquities). In light of this increased vigilance, support for a federal statute of limitations is likely to increase.

59. See 1986 Senate Hearings, supra note 54, at 102-09.

60. The New York statute of limitations is discussed in Kunstsammlungen $\mathrm{Zu}$ Weimar v. Elicofon, 678 F.2d 1150, 1161-62 (2d Cir. 1982). New Jersey has adopted a "discovery rule" under which the cause of action in a replevin suit only accrues when the owner "knew, or reasonably should have known . . . the possessor" of the stolen objects. O'Keeffe v. Snyder, 170 N.J. Super. 75, 405 A.2d 840 (App. Div. 1979), rev'd, 83 N.J. 478, 416 A.2d 862 (1980).

61. These statutes were sponsored by the Metropolitan Museum of Art. Lowenthal, IFAR Opposes N.Y. Bill Instituting Three-Year Limit on Suits to Recover Stolen Art, IFARREPORTS, Oct.Nov. 1985, at 3 . 
the loss of the artifact is discovered. Publication in a museum bulletin would not help these countries. ${ }^{62}$

Private collectors, dealers and museums ${ }^{63}$ are most affected by the $M c^{-}$ Clain decision. This community is politically well connected ${ }^{64}$ wealthy, committed to the collection of antiquities and, as long as McClain remains good law, subject to liability under civil and criminal law. For this reason, legislative efforts to reverse $\mathrm{McClain}$ are likely to receive continuing support. The arguments for reversing the McClain decision and legislating a restricted definition of stolen have some validity. However, in light of the harm caused by the search for artifacts, the economics of the antiquity market, and the nature of the common law theft rule, such a restrictive definition should be opposed.

\section{A Rationale for ENForcing Umbrella OWNERShip Statutes}

There are strong economic arguments for a rule that places liability on purchasers. In addition, there are legal precedents that provide a model for the enforcement of umbrella statutes by United States courts.

\section{A. Economic Analysis}

An economic analysis of the market for antiquities suggests that the most effective means of slowing new thefts is to place liability for the purchase of stolen antiquities on buyers. Under the common law, when an object is stolen from an owner and sold to a third party, if the owner locates the property and the thief is judgment proof ${ }^{65}$ or otherwise un-

62. There are more than 500 museums in New York state. Id. Therefore, publication would not necessarily render the stolen object quickly identifiable. The bill was vetoed by Governor Cuomo. See supra note 54. He stated that the legislation did not "balance fairly the legitimate interests of foreign countries in recovering their lost or stolen art work with the legitimate interests of museums or other good faith purchasers of art." N.Y. Times, July 29, 1986, at C14, col. 3.

63. In hearings held in the Senate, the McClain opposition was dominated by collectors and museum curators. See generally 1986 Senate Hearings, supra note 54; 1985 Senate Hearings, supra note $21 ; 1978$ Senate Hearings, supra note 1 . When presenting S. 605 Senator Moynihan stated that he was appearing "in some sense as chairman of the board of the Hirschorn Museum and Sculpture Garden [located in Washington, D.C.]. . . . [which collects] pre-Columbian sculpture . . . " 19S5 Senate Hearings, supra note 21, at 6. Others testifying in favor of S. 605 included Douglas Ewing, President of the American Association of Dealers in Ancient, Oriental and Primitive Art. Thomas Solley, the director of the Indiana University Art Museum proposed that "art-rich nations . . protect their cultural patrimony through strict laws and enforcement." Id. at 123. He claimed that "[t]he plea of poverty lacks credibility when one considers how effectively the Chinese have preserved their heritage even through periods of extreme political upheaval." Id. Bernard Bothmer, a retired member of the Brooklyn Museum made the oft-repeated argument that "it is this country and our allies in Europe who are the true preservers of the cultural heritage of almost all countries of the ancient world, and instead of discouraging the importation of relics of the past, I would encourage and applaud it ...." Id. at 133 .

64. See J. Hess, The Grand AcQuisrtors 2-4 (1974) (discussing illegal dealings at New York's Metropolitan Museum of Art and fact that directors are extremely powerful individuals).

65. In this instance, a thief would be considered judgment proof if she did not have sufficient funds to compensate the purchaser or could not be located. 
available, the third party purchaser must return the object to the original owner without compensation. Under the common law rule, if the thief was not judgment proof, the purchaser of the stolen property would still have to return the stolen goods to the original owner. The purchaser, however, could bring an action against the thief and obtain a damage award equivalent to the purchase price of the property. The argument underlying this rule is that third party buyers will be able to investigate and police the market better than will owners victimized by theft. The relevant question is how do we allocate risk to best prevent theft. ${ }^{86}$

The economic framework for analyzing the theft rule can be applied to the trade in stolen antiquities. ${ }^{67}$ In the market for antiquities, the owners' ability to protect against theft is particularly limited, while buyers can generally investigate and avoid the purchase of stolen goods. There are several reasons why the owner cannot prevent theft. The value of antiquities on the international market provides a strong incentive for theft. ${ }^{68}$ The source countries' level of development hinders their ability to protect antiquities. Finally, many artifacts remain underground and a comprehensive system of policing the countryside would be needed in order to prevent unauthorized looting. ${ }^{69}$

Thus, the antiquities market is an ideal case for strictly applying the common law rule, and ensuring that an original owner, such as a source country, will have a valid claim for the return of stolen antiquities. ${ }^{70}$ The number of buyers of artifacts is few in comparison with the number of antiquity sites. ${ }^{71}$ For this reason, it is more efficient to police the activities of antiquity purchasers than to try to protect archaeological sites. Monitoring purchasers is less costly than protecting innumerable sites commonly located in inhospitable and inaccessible regions of the world. Thus

66. There has been considerable scholarly debate over whether a rule that places liability on the owner or one that places liability on the buyer is the most efficient means of limiting theft. See A. ScHWARTz \& R. SCOTT, supra note 55, at 476-79. For a comparative analysis of theft rules in various countries see Levmore, Variety and Uniformity in the Treatment of the Good-Faith Purchaser, 16 J. LEg. STUD. 43 (1987). What is important about this debate is the efficiency framework used to determine who should bear the risk of theft and its application to the antiquities market.

67. For an expanded analysis of the economic principles of the theft rule see Levmore, supra note 66 , at $45-49$.

68. The price for artifacts in developing countries is much lower than what can be received for these objects on the international market. See Craven, A Suggested Format for Funding the Preservation of Pre-Columbian Patrimony in the Americas, 11 J. Findd ARCHAEOLOGY 425-26 (1984); Wellborn, supra note 15 , at 79.

69. Many of those sites which are known to contain valuable relics are located in remote areas. It is difficult to prevent the looting of these sites. Furthermore, enforcement officials are frequently bribed to ensure undisturbed excavation. See supra note 22.

70. This assumes that the country can demonstrate ownership, and that the applicable statute of limitations has not expired.

71. In spite of the recent growth in the antiquity trade, the number of undiscovered sites and buried ruins far exceeds the number of buyers and sellers of antiquities. There are innumerable sites of known, and unknown, archaeological ruins located throughout the world. Every location of an early settlement is a potential source of artifacts. The collection of antiquities, however, is limited to wealthy collectors and museums in a few countries. Not only are there fewer collectors than sites, it is far easier to locate and police their purchases than to protect the archacological sites themselves. 
an efficient police system would concentrate on the behavior of purchasers, instead of trying to protect the archaeological sites themselves.

Further justification for imposing liability on the buyers of antiquities arises from the fact that these purchasers generally have the knowledge and the resources to investigate the validity of an antiquity's title. ${ }^{22}$ Most artifact-rich nations that have enacted blanket ownership statutes require that all antiquities be registered. ${ }^{73}$ For antiquities exported after the passage of an umbrella ownership statute, the buyer can demand proof of registration. Absent a registration document, the prospective purchaser could request verification that the object had been exported from the country of origin prior to the enactment of applicable umbrella statutes. ${ }^{74} \mathrm{Col}-$ lectors will be able to avert the purchase of stolen antiquities by carefully inspecting the "title" of antiquities that are for sale. By determining the validity of items on the market, purchasers will deter sellers from dealing in "stolen" works. The demand for stolen antiquities will diminish. Accordingly, the incentive for continued looting of archaeological sites will decline.

\section{B. Legal Analysis}

The legal argument for enforcing a foreign nation's blanket ownership declaration draws upon the concept of national ownership of American artifacts articulated in the Archaeological Resources Protection Act of 1979 (ARPA), ${ }^{75}$ judicial interpretation of state statutes that declare that protected wildlife is owned by the state for purposes of applying the NSPA,$^{76}$ and separation of powers concerns in the act of state doctrine.

72. A plausible argument can be made that buyers are also the best insurers. An efficient legal rule will allocate liability to the party best situated to insure against the risk of loss. See A. SCHWARTZ \& R. SCOTT, supra note 55, at 476 . The cost of insurance will vary depending on information costs and the likelihood of theft. It will be difficult and expensive for countries to insure against the theft of antiquities since source nations cannot protect existing sites and often do not know where antiquities are buried. It will be less expensive for purchasers to insure because their collections can be easily documented and better protected. Thus the efficient rule would place the risk of loss on the buyer.

73. Mexico, concomitant with the enactment of umbrella statutes, required that all antiquities be registered. McClain I, 545 F.2d at 993 . If a country with an umbrella statute did not require existing artifacts to be registered, it would be unfair to enforce the common law rule. A buyer would be unable to determine whether an antiquity offered for sale was stolen.

74. The usefulness of a requirement that purchasers have proper documentation of an antiquity's provenance is limited by the likelihood of fraud. It is common for export licenses to be forged. See supra note 22. See also Kingdom of Spain v. Christie, Manson \& Woods Ltd. 1 W.L.R. 1120 (1986) (discussing fraudulent documentation of Spanish export license for a painting by Goya). It would be difficult, without the adoption of an international licensing system, to force a good-faith purchaser of an antiquity with forged licenses to forfeit the work. The rule could, however, require purchasers to exercise a high standard of care that would determine all but the most sophisticated forgeries.

75. 16 U.S.C. $\$ \S 470$ aa-ll (1982).

76. Analogies to the ARPA and state wildlife statutes have been articulated by Ely Maurer, Assistant Legal Adviser, Department of State, 1985 Senate Hearings supra note 21, at 43-47; Note, supra note 26 , at $327-28$. These analyses have not recognized that umbrella ownership statutes are not equivalent to more traditional forms of ownership. 
Further, United States courts have demonstrated a willingness to give special consideration to the unique nature of the art market when applying commercial transaction standards.

\section{Recognition of Similar Statutes by United States Courts}

The Archaeological Resources Protection Act is similar to an umbrella statute. ${ }^{77}$ This legislation provides that artifacts located above and below the ground on public and Indian lands are national property. Anyone found transporting these artifacts is subject to criminal sanctions under the NSPA. ${ }^{78}$

If a looter unearthed a Hopi Basket from a gravesite on National Park land and sold it to a dealer in New York, why would the Government's claim to own this artifact be any more valid than Mexico's claim to own

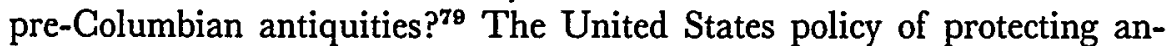
tiquities is similar to that adopted by other source countries. Under the ARPA, the United States declares itself owner of antiquities that have not yet been discovered. It is true that the ARPA does not apply to artifacts found on private property. However, the United States' ability to declare national ownership and subsequently prosecute dealers in Indian artifacts under the NSPA is analogous. ${ }^{80}$

The conservation laws enacted by Louisiana ${ }^{81}$ and Georgia, ${ }^{82}$ which assert state ownership of alligators, are also similar to umbrella ownership statutes. Like umbrella statutes, these laws are the sole basis of ownership. Courts have found that the transportation of wildlife, which a state claims to own based on a legislative decree, is a violation of the NSPA. ${ }^{83}$ The policy and reasoning behind these decisions is consistent with the Fifth Circuit's decision to enforce Mexico's umbrella ownership statute in McClain $I^{84}$

77. McClain "gives effect to the ownership right of . . . [Mexico] . . . in the same way as the Archaeological Resources Protection Act preserves national and native American ownership of resources found to require special protection within the United States." 1985 Senate Hearings, supra note 21, at 47 (testimony of Ely Maurer, Assistant Legal Adviser, Department of State).

78. Id.

79. Id. at 44 .

80. The limited scope of United States' antiquity laws might be explained by the fact that there is a sufficient domestic market for Indian artifacts such that umbrella statutes, designed to prevent the export of antiquities, are unnecessary.

81. See La. Rev. Stat. AnN. §56-3 (West Supp. 1986).

82. See GA. Code ANN. $\S 27-1-3$ (1986); see also Dept. of Natural Resources v. Keating, 238 Ga. 605, 234 S.E.2d 519 (1977) (upholding state ownership of wildlife).

83. United States v. Klapisch, No. 77-620, slip op. (E.D.N.Y. July 28, 1978) (Louisiana's ownership of alligators grounds for holding that individual transporting alligator skins violates the NSPA); United States v. Plott, 345 F. Supp. 1229, 1232 (S.D.N.Y. 1972) (transporting alligators trapped in Georgia violates NSPA).

84. As noted by Maurer, 1985 Senate Hearings, supra note 21 and Note, supra note 26, at 331 $\&$ nn. 138-40, recognition of a country's ownership of artifacts would also be analogous to recognition of the legal right nations possess in subsoil minerals. See generally G. Hill, Treasure Trove in Law and Practice from the Earlest Time to the Present Day (1936) (discussing fact that many nations claim ownership of treasure buried in ground regardless of whether this land is pri- 


\section{Act of State Doctrine}

Under the act of state doctrine, United States courts refrain from ruling on the validity of "public acts a recognized foreign sovereign power committed within its own territory." 85 The doctrine is grounded in separation of powers concerns. The judiciary may decide not to involve itself in evaluating the acts of a foreign state carried out within its own border because of the potential for conflict with the executive's exercise of the foreign affairs power. ${ }^{86}$ In the case of umbrella statutes, a court's nonrecognition of such a statute may conflict with foreign policy goals of the executive branch, including a wish to show support for the government of a particular country. ${ }^{87}$

The State Department, the Department of Justice and the United States Information Agency oppose legislation that would reverse the $M c$ Clain decision. ${ }^{88}$ Many artifact-rich nations are located in sensitive geopolitical regions. Enforcing laws that seek to deter looting and the theft of antiquities abroad is a simple and inexpensive method by which the United States can build better relations with friendly governments in these regions. ${ }^{89}$ The State Department also argues that it would be very difficult to justify to foreign governments the elimination of a presently available remedy, one which follows from long standing common law principles and which parallels relief expressly provided in the case of archaeological resources declared to be the property of the United States. ${ }^{90}$

vately or publicly owned). These ownership claims do not depend on the state having a possessory interest in that property. For example, if a state has nationalized oil and oil is then discovered on a private citizen's land, and then shipped into the U.S., the oil will still be considered the property of the country of origin. 1985 Senate Hearings, supra note 21, at 46 (testimony of Ely Maurer, Assistant Legal Adviser, Department of State). See also Restatement (SECOND) of Foreign RelaTIONS LAW of THE UNiTED STATES, $\S 41$ comment d, illustration 8 (1965) (statute nationalizing oil is an act of state).

85. See Banco Nacional de Cuba v. Sabbatino, 376 U.S. 398, 401 (1964) (judiciary will not examine validity of taking by foreign government within its own territory).

86. Id. at 412 .

87. There are important government concerns in art-related issues. The act of state doctrine was discussed in Federal Republic of Germany v. Elicofon, 536 F. Supp. 813, 825-26 (E.D.N.Y. 1978) in which the Grand Duchess of Saxony-Weimar claimed that payments were due her following the expropriation of two Durer paintings by the German government. The court held that the act of state doctrine precluded an inquiry into the validity of the German government's action. Id. at 825. In so holding, the court recognized that art-related transactions can become issues of great diplomatic sensitivity, a finding which reinforced the court's desire to refrain from passing on the legality of West Germany's act.

88. See 1986 Senate Hearings, supra note 54, at 8-36 (statements of John C. Keeney, Deputy Assistant Attorney General, Criminal Division, Department of Justice; Ely Maurer, Assistant Legal Adviser, Department of State; Thomas E. Harvey, general counsel and congressional liaison, United States Information Agency.)

89. See Constable, The Looting of Ancient Sites and the Illicit Trade in Works of Art, $10 \mathrm{~J}$. Field ARchaeology 482, 484 (1983).

90. See 1985 Senate Hearings, supra note 21, at 47. 


\section{Judicial Recognition of the Unique Nature of Art}

United States courts have recognized the distinctive nature of the art market and have modified legal standards accordingly. ${ }^{91}$ In Jeanneret $v$. Vichey, ${ }^{92}$ the Second Circuit took the novel position that the illegal export of a work of art could constitute a sufficient "cloud" on its title to render the seller in violation of the implied warranty of title. ${ }^{93}$ The court's analysis was unusual because illegal export usually does not affect an item's title. The court based its conclusion on the fact that the art market is particularly sensitive to allegations of impropriety, and thus the illegal export of a work may prohibit its sale "to any reputable art-dealer or auction house."

Similarly, a New York court adopted a unique standard of the "good faith purchaser" whether a buyer has acted in good faith, the court traditionally compares the buyer's actions with common industry practice. If the buyer acted in accordance with acceptable standards, she is considered to have acted in good faith. An exception to this rule was made in Porter $v$. Wertz. ${ }^{96}$ In this case, a gallery that purchased a Utrillo painting claimed it had acted in good faith, and that its failure to inquire into the work's title was consistent with industry practice. The New York Supreme Court agreed with the defendant that it was common for galleries not to inquire into an art work's title. However, the mere fact that galleries usually do not investigate title was not a sufficient ground for holding that the purchasers of the Utrillo acted in good faith. Instead, the court held that the defendant's argument confirmed the need for greater investigation by merchants as "commercial indifference to ownership ... facilitates traffic in stolen works of art."

91. "In many situations, the art aspect of a commercial transaction is treated as unique and not within the broad provisions of the U.C.C." FELDMAN \& WEIL, supra note 35 , at $§ 9.2 .8$.

92. 541 F. Supp. 80 (S.D.N.Y.), rev'd, 693 F.2d 259 (2d Cir. 1982).

93. Jeanneret, an established art dealer in Geneva, purchased a Matisse from Anna and Luben Vichey. The painting had been previously held in Italy. After trying unsuccessfully to sell the painting in Europe, Jeanneret became aware that the Italian government was seeking the work on the grounds that it had been illegally exported. She then sought to return the painting to the Vicheys, and when they refused, brought suit on grounds of a breach of express and implied warranties of title. 693 F.2d at 260-61. The district court held that U.C.C. $\$ 2-312$ had been breached when the buyer was faced with a claim on title by the Italian Government. Jeanneret v. Vichey, 541 F. Supp. 80, 82-83 (S.D.N.Y. 1982). On appeal, the Second Circuit noted that the claims made by the Italian government prevented Jeanneret from selling the painting to any reputable art dealer or auction house and thus this constituted a "heavy cloud" on title. 693 F.2d at 268. The court accepted a lesser standard for showing a clouded title, modifying U.C.C. $\$ 2-312(1)(b)$. For discussions of this case, see Note, Jeanneret v. Vichey: Sales of Illegally Exported Art Under the Uniform Commercial Code, 6 Nw. J. INT'L L. \& Bus. 275 (1984); Comment, Jeanneret v. Vichey: Evaporating the Cloud, 15 N.Y.U. J. INT'L L. 999 (1983).

94. Jeanneret v. Vichey, 693 F.2d at 268 (footnote omitted).

95. The Code characterizes "good faith" as "honesty in fact and the observance of reasonable commercial standards of fair dealing in the trade." U.C.C. $\$ 2-103(1)(b)$ (1977).

96. 68 A.D.2d 141, 416 N.Y.S.2d 254 (1979).

97. Id. at 149,416 N.Y.S.2d at 259; see also Taborsky v. Marony, No. 83-2533, No. 83-2560 
Gourts were willing to adjust legal definitions in Jeanneret $v$. Vichey and Porter v. Wertz to conform to the unique characteristics of the art market. Similarly, in this instance, the nature of antiquities necessitates an expansive definition of ownership and stolen. For this reason, courts should follow the McClain and Hollinshead lead in adjusting the definition of ownership to recognize the validity of umbrella ownership statutes.

\section{Towards Effective ENForcement of Umbrella Statutes}

Several important limitations must be overcome if the United States courts' enforcement of umbrella statutes is to limit new thefts. First, as critics of the McClain decision maintain, enforcement of these laws may permit foreign countries to free-ride on United States enforcement mechanisms. Second, museums and collectors fear that recognition of source country ownership of antiquities may lead to an onslaught of litigation for the return of works held in the United States for many years. Finally, even if these obstacles are overcome, the effectiveness of this strategy may be limited by the fact that the looting of artifacts is often a subsistence occupation.

\section{A. Monitoring Source Nations}

The free-rider problem stems from the concern that instead of protecting their own borders, source countries may rely exclusively on the prosecution of looters by the United States. Monitoring of artifact-rich nations with umbrella ownership statutes could limit this problem. The United States should insist that all countries claiming ownership of their cultural patrimony enforce the umbrella laws within their borders. ${ }^{88}$ The State Department or an executive committee ${ }^{9 \theta}$ should be responsible for determining which countries are consistently enforcing their own umbrella ownership statutes. ${ }^{100}$

Cr. 296 (7th Cir. Sept. 7, 1984) reprinted in FeldMaN \& WeIL, supra note 35, at $\$ 9.2 .4$. (following holding in Porter $v$. Wertz). But see Johnson \& Johnson Prod. v. DAL Int'l Trading, 798 F.2d 100,104 (3d Cir. 1986) (inquiry into reputation of seller not required by purchaser of grey market goods).

98. To successfully enforce an umbrella statute, a source country must require, at the time the umbrella statute is enacted, the registration of all antiquities held in private and public collections. See supra note 73 and accompanying text. All antiquities exported after the umbrella statute was enacted that are not registered can be considered stolen.

If a government did not have an effective registration program or did not otherwise enforce its own umbrella statute, enforcement of these statutes by the United States would allow these countries to free-ride on United States enforcement mechanisms.

99. An example of such a committee is the Cultural Property Advisory Committee set up in accordance with the Cultural Property Implementation Act (CPIA) to make recommendations on when the provisions of the act should be enforced. 19 U.S.C. $\$ 2605$ (1983). The CPIA is discussed supra note 36.

100. United States courts and the Customs Service could then contact the United States monitoring agency to determine whether a particular country is enforcing ownership laws and thus whether the United States should enforce this country's umbrella statute. A model for this approach can be found in O'Keeffe v. Snyder, 170 N.J. Super. 75, 405 A.2d 840 (App. Div. 1979), rev'd, 83 N.J. 478, 
An optimal legal rule would encourage host countries to use all available methods to limit exportation, provide incentives for buyers to police the market by investigating the provenance of goods prior to purchase, ${ }^{101}$ and enable foreign countries to prosecute importers of stolen artifacts. To deter further free-riding it is necessary to promulgate a rule that forces purchasers of stolen artifacts to forfeit these objects only when they are worth more than a set value, for example $\$ 5,000$. In this way, host countries have an incentive to restrict the export of antiquities, since there is no way to recover objects worth less than $\$ 5,000$. Moreover, liability for the purchase of stolen antiquities is only placed on purchasers of expensive artifacts. These buyers are best situated to determine if an antiquity has been legally imported. ${ }^{102}$

\section{B. The Retroactive Effect of Umbrella Statutes}

The United States should not enforce umbrella statutes retrospectively. Antiquities removed from the country of origin prior to the adoption of national ownership statutes would not be subject to civil or criminal action in United States courts. This restriction sharply limits the scope of this proposal. Artifact-rich nations will not be able to seek the return of some of their most important "cultural property."103 That umbrella statutes will not be applied retroactively should reassure many of the museum directors and collectors who have lobbied for legislation to overrule $\mathrm{Mc}$ Clain. The Metropolitan Museum of Art need not fear that the calyx krater, which some argue was looted from an important historical site,

416 A.2d 862 (1980). In this case the court held that an owner must act with "due diligence" in seeking the return of stolen art in order to toll the statute of limitations. Id. at 493 . The case involved the theft in 1946 of three small Georgia O'Keeffe paintings from a New York gallery operated by O'Keeffe's husband, Alfred Stieglitz. O'Keeffe did not report the theft until 1972. The court reasoned that as long as the owner acted diligently, her rights of title were preserved. The equitable principles cited by the court in applying the discovery rule in this case are analogous to a broad acceptance of a foreign government's claim to stolen antiquities. The discovery rule holds that in an appropriate case a cause of action will not accrue until the injured party discovers the factual basis of the cause of action. Id. at 491. Principles of adverse possession hold that one can acquire title to personal property providing the possession is "hostile, actual, visible, exclusive, and continuous." Id. at 494. The court cited the difficulty of meeting this standard with works of art that are privately displayed in homes. The situation is even more difficult in the antiquity trade, a market notorious for its clandestine procedures. See Bator, supra note 5, at 290.

Developing countries should be held to a similar standard. As long as efforts are made to limit theft and seek the return of stolen antiquities, a nation's umbrella ownership laws should be upheld. Under this rule, if the country does not actively monitor the art market to locate stolen works, the statute of limitations may bar their recovery of stolen antiquities.

101. See Porter v. Wertz, 68 A.D.2d 141, 416 N.Y.S.2d 254 (1979).

102. See supra notes 70-74 and accompanying text. One limitation of this proposal is that it could result in the further breaking up of large antiquities into smaller units worth less than $\$ 5,000$. There is not, however, a clear relationship between the size of an antiquity and its value. In the few instances where this rule may encourage further destruction of artifacts, such as in the case of a large Mayan Stela, an exception to the rule could be made.

103. For example, the Greek government will not be able to obtain the return of the Elgin Marbles from England. See generally Merryman, supra note 18 (discussing efforts to have British Museum return Elgin Marbles to Greece). 
will be returned to Greece. ${ }^{104}$ United States recognition of artifact rich nations blanket ownership of antiquities is primarily concerned with preventing the recurrence of this pillage.

\section{G. Subsistence Looting: An Intractable Problem}

The recognition of source countries ownership claims by United States courts will assist in halting the trade in stolen antiquities. ${ }^{105}$ In many countries the looting of archaeological sites is a subsistence occupation. ${ }^{106}$ For this reason, it will be difficult to use legal sanctions to halt the activities of impoverished local populations. Furthermore, in many countries with strict laws against the export of antiquities, administrative officials willing to provide forged export certificates for antiquities dealers will circumvent the effect of these statutes. Since the United States will only enforce the umbrella statutes of nations which consistently apply this legislation internally, indigenous corruption may prohibit the United States from recognizing many countries' blanket ownership decrees.

In addition, many artifact rich countries have not passed umbrella ownership statutes. There will be an increasing incentive to trade in antiquities from those nations without blanket ownership laws. Furthermore, the enforcement of umbrella statutes will only deter trade in stolen antiquities. Illegally exported works, that are not stolen, will continue to be marketed without restriction.

\section{Conclusion}

American courts should recognize a strict common law rule, broadly interpreting the property laws of artifact-rich countries. Enforcement of this rule would enable courts to use the NSPA and common law replevin to slow the trade in stolen antiquities. Such enforcement makes economic sense. To the extent that it requires a modification of legal standards, it can be analogized to similar legal changes made in other art-related areas. The type of pre-purchase investigation that such a liability system would encourage has already been adopted by a number of leading university museums. ${ }^{107}$ The success of these policies demonstrates the feasibility of

104. See K. MEYER, supra note 4, at 86-100 (discussing this Euphronios vase which the Italian police claim was stolen from an Etruscan tomb).

105. The price of pre-Columbian art has dropped considerably, perhaps in response to the danger of purchasing stolen antiquities since the $\mathrm{McClain}$ decision. The market in tribal art exported from countries which either do not have umbrella statutes or have not sought to enforce them in United States courts has not been affected. See Sotheby's, Important TRIBAL ART (Nov. 18, 1986); Sotheby's, PRE-Columbian ART (Nov. 24, 1986). In other instances, purchasers of antiquities have refused to buy objects without detailed export and ownership information. See United States v. One 18th Century Columbian Monstrance, 797 F.2d 1370, 1373 (5th Gir.) reh'g denied, 802 F.2d 837 (1986) (San Antonio Museum of Art concerned when seller of Monstrance asked Museum not to ask: Colombian Government about piece's export).

106. See L. Prott \& P. O'KeEfe, supra note 23, at 18, 369.

107. See, e.g., Biddle, New Directions: The Director Writes, ExpenItion, Spring 1980, at 2 (pol- 
the legal rule that this interpretation of ownership would engender. The trade in stolen antiquities continues to cause irreparable damage to the historical record of artifact-rich nations. Recognition of umbrella ownership statutes is the most effective means of deterring this illicit trade.

icy of the University of Pennsylvania Museum); Dixon, More Policy Statements on the Acquisition of Art and Antiquities, 15 Current ANThropology 197 (1974) (policies of California State University, Long Beach, and University of California, Berkeley); Harvard University Approves Policy Governing Acquisition of Art Objects From Foreign Countries, 14 CuRATOR 83, 87 (1971) (policy of Harvard University Museum). 